\title{
The effects of starch and rapidly degradable dry matter from concentrate on ruminal digestion in dairy cows fed corn silage-based diets with fixed forage proportion
}

\author{
C. Lechartier ${ }^{*} t^{1}$ and J.-L. Peyraud ${ }^{*} t^{2}$ \\ *INRA, UMR1080 Production du Lait, F-35590, St-Gilles, France \\ †Agrocampus Ouest, UMR1080 Production du Lait, F-35000, Rennes, France
}

\begin{abstract}
This study investigated the effects of the type (starch vs. nonstarch) and rate of ruminal degradation of carbohydrates from the concentrate on digestion in dairy cows fed corn silage-based diets. Six ruminally cannulated cows were assigned to 6 treatments in a $6 \times 6$ Latin square design. Treatments were arranged in a 3 $\times 2$ factorial design. Two starch levels [25 and $41 \%$ dry matter (DM) for low starch (LS) and high starch (HS) diets, respectively] were obtained by replacing starchrich feedstuffs by nonstarch feedstuffs. These starch levels were combined with slowly, moderately, and rapidly rumen-degradable feedstuffs to obtain 3 levels of rapidly degradable carbohydrates from concentrate $(18$, 23 , and $28 \% \mathrm{DM})$. These levels were estimated from the DM disappearance of concentrate after $4 \mathrm{~h}$ of in sacco incubation (CRDM). Wheat and corn grain were used as rapidly degradable and slowly degradable starch feedstuffs, respectively. Soybean hulls and citrus pulp were used as slowly degradable and rapidly degradable nonstarch feedstuffs, respectively. No interaction effect was found between dietary starch content and CRDM on $\mathrm{pH}$ range, volatile fatty acid (VFA) range, or VFA profile. Increasing CRDM led to a linear decrease in acetate-to-propionate ratio (from 2.7 to 2.1), and a linear increase in the $\mathrm{pH}$ and VFA ranges (from 0.86 to $1.12 \mathrm{pH}$ units and from 34 to $56 \mathrm{~m} M$, respectively). Feeding HS diets decreased acetate-to-propionate ratio (2.6 vs. 2.0$)$ and increased $\mathrm{pH}$ range (0.89 vs. $1.04 \mathrm{pH}$ units), but had no effect on VFA range. Increasing CRDM linearly decreased mean ruminal $\mathrm{pH}$ in LS diets but linearly increased mean ruminal $\mathrm{pH}$ in $\mathrm{HS}$ diets. Fibrolytic activity was unaffected in LS diets but decreased strongly in HS diets (from 62 to 50\%). These findings suggest that $\mathrm{pH}$ regulation differs on a shortterm and on a longer-term basis. In the short-term, in-
\end{abstract}

Received March 24, 2010.

Accepted January 24, 2011.

${ }^{1}$ Current address: École Supérieure d'Agriculture, 55 rue Rabelais, 49007 Angers cedex, France.

${ }^{2}$ Corresponding author: jean-louis.peyraud@rennes.inra.fr creasing CRDM increased the rate of VFA production, which may have been partly buffered under LS diets due to the higher cation exchange capacity of nonstarch feedstuffs compared with starch-rich feedstuffs. In the longer term, feeding starch reduced fibrolytic activity, which may have led to lower total VFA production and higher mean $\mathrm{pH}$. The results of this experiment clearly show that both fermentative characteristics of the concentrate and dietary starch content should be taken into account when formulating diets to prevent subacute ruminal acidosis and to predict VFA profile.

Key words: starch, rate of degradation, rumen $\mathrm{pH}$, dairy cow

\section{INTRODUCTION}

Dairy cow feeding systems aim to maximize milk production via high-starch diets, which can lead to SARA (Plaizier et al., 2008). Subacute ruminal acidosis is defined as periods of moderately depressed ruminal $\mathrm{pH}$ (Beauchemin et al., 2003), and $\mathrm{pH}$ depressions below 5.6 to 5.8 are generally accepted as threshold values. It leads to a drop in acetate-to-propionate ratio, fiber digestibility, milk fat content, and DMI (Plaizier et al., 2008).

Replacing nonstarch feedstuffs by starch-rich feedstuffs without modifying the forage proportion of the diet usually leads to a decrease in the molar proportion of acetate and an increase in the molar proportion of propionate (Robinson et al., 1986; Ipharraguerre et al., 2002; Voelker and Allen, 2003b). The effect of the type of carbohydrate on mean ruminal $\mathrm{pH}$ is less systematic. Huhtanen (1988) and Silveira et al. (2007) reported a decrease in ruminal $\mathrm{pH}$ when replacing sugar beet pulp with barley. Conversely, Voelker and Allen (2003b) did not observe variation in ruminal $\mathrm{pH}$ when substituting sugar beet pulp with high-moisture corn, and Robinson et al. (1986) did not observe variation in ruminal $\mathrm{pH}$ when substituting a mixture of sugar beet pulp and soybean hulls with corn hominy feed and tapioca.

The use of nonstarch feedstuffs is often associated with a low ruminal fermentation rate (Allen, 1997), 
and trials having tested the effects of replacing starchrich with nonstarch concentrates were not designed to separate the effects of starch content and degradation rate, due to the lack of a criterion to quantify the dynamics of degradation of the feedstuffs. Data on the in sacco degradability of over 160 feedstuffs were recently compiled in tables of feed material composition and nutritional value (INRA-AFZ, 2004). Large differences exist in kinetics of ruminal DM degradation and effective degradability among nonstarch feedstuffs. For example, citrus pulp is much more rapidly degraded than soybean hulls, and can lead to a lower in vivo $\mathrm{pH}$ than corn grain or beet pulp (Malestein et al., 1984). Using these differences between feedstuffs, Lechartier and Peyraud (2010) have formulated diets presenting contrasting contents of DM degraded during $4 \mathrm{~h}$ of in sacco incubation without modifying dietary NDF and starch content. These authors have shown that increasing the amount of rapidly degradable DM strongly decreases ruminal $\mathrm{pH}$ and the acetate-to-propionate ratio. Furthermore, in vitro studies have shown that, independently of its effect on $\mathrm{pH}$, the fermented substrate can modify acetate and propionate production (Calsamiglia et al., 2008).

The objective of this study was to examine the effects of type of carbohydrate (nonstarch vs. starch-rich), and of the content of rapidly degradable DM of carbohydrate-rich feedstuffs and their interactions on ruminal fermentation in dairy cows fed TMR with similar forage proportion.

\section{MATERIALS AND METHODS}

\section{Animals and Experimental Design}

The trial was conducted as a $6 \times 6$ Latin square design with a $3 \times 2$ factorial arrangement of treatments with 6 ruminally cannulated lactating Holstein cows (means $\pm \mathrm{SD}: 635 \pm 76 \mathrm{~kg}$ of BW; $70 \pm 11$ of DIM; $40.1 \pm 3.9 \mathrm{~kg} / \mathrm{d}$ of milk yield; $33.9 \pm 8.4 \mathrm{~g} / \mathrm{kg}$ of milk fat content; $29.5 \pm 3.1 \mathrm{~g} / \mathrm{kg}$ of milk protein content). The trial included a 2 -wk pre-experimental adaptation period to monitor voluntary DMI. Each experimental period was $14 \mathrm{~d}$ in duration, with $10 \mathrm{~d}$ of treatment adaptation and $4 \mathrm{~d}$ of data collection.

The ruminal cannulas measured $123 \mathrm{~mm}$ in diameter. The procedures relating to surgery, care, and use of animals for experiments were approved by an animal care committee of the French Ministry of Agriculture, in accordance with French regulations (decree-law 2001-464, May 29, 2001). Cows were housed in individual tie stalls and had free access to water throughout the trial. Cows were milked twice daily at 0700 and $1730 \mathrm{~h}$.

\section{Experimental Treatments and Feeding Management}

Six TMR were formulated with different levels of starch and different amounts of rapidly degradable carbohydrates from the concentrate. The forage-toconcentrate ratio was kept constant and equal to 40:60. The 2 starch levels were 25 and $41 \% \mathrm{DM}$ and they were combined with slowly, moderately, and rapidly rumendegradable concentrate (S, $\mathbf{M}$, and $\mathbf{R}$, respectively). The compositions of the various TMR were: 1) slowly degradable concentrate and low starch (S-LS); 2) moderately degradable concentrate and low starch (MLS); 3) rapidly degradable concentrate and low starch (R-LS); 4) slowly degradable concentrate and high starch (S-HS); 5) moderately degradable concentrate and high starch (M-HS); and 6) rapidly degradable concentrate and high starch (R-HS).

For each feedstuff, the content of rapidly degradable DM (RDM; \%) was defined as the feedstuff's DM content that disappeared during the first $4 \mathrm{~h}$ of in sacco incubation. The RDM was calculated from in sacco DM degradation parameters $(a, b$, and $c)$ compiled in the INRA tables of composition and nutritional value of feed materials (INRA-AFZ, 2004):

$$
R D M=a+b \times\left(1-\mathrm{e}^{-c t}\right),
$$

where $a=$ soluble DM fractions (\%); $b=$ slowly disappearing DM fractions (\%); $c=$ fractional rate of disappearance of DM; and $t=$ time of incubation $(4 \mathrm{~h})$.

The concentrates were formulated to provide approximately 18,23 , and $28 \%$ of $\mathrm{RDM}$ in $\mathrm{S}, \mathrm{M}$, and $\mathrm{R}$ TMR, respectively. The dietary content of RDM from the concentrate (CRDM) was calculated according to the formula:

$$
C R D M=\sum_{i=1}^{n} p_{i} \times R D M_{i}
$$

where $R D M_{i}$ is the content of rapidly degradable DM of feedstuff $i, p_{i}$ is the dietary proportion of feedstuff $i$, and $n$ is the number of feedstuffs in the TMR concentrate mixture.

Wheat and citrus pulp are RDM-rich (68 and $53 \% \mathrm{DM}$, respectively), whereas corn grain and soybean hulls contain less RDM (35 and 20\% DM, respectively). The proportion of wheat was increased, whereas the proportion of corn was decreased to formulate $\mathrm{S}, \mathrm{M}$, and $\mathrm{R}$ diets rich in high-starch concentrates, and the proportion of citrus pulp was increased, whereas the proportion of soybean hulls was decreased to formulate $\mathrm{S}, \mathrm{M}$, and $\mathrm{R}$ diets rich in low-starch concentrates. 
The concentrates were also formulated to obtain 6 TMR supplying a similar amount of $\mathrm{NE}_{\mathrm{L}}(1.70 \mathrm{Mcal} /$ $\mathrm{kg}$ of DM) and protein digestible in the small intestine (PDI; 9.4\% DM; INRA, 1989). This implied introducing a few percent of ground wheat straw into the concentrate of HS diets to compensate for the lower $\mathrm{NE}_{\mathrm{L}}$ content of low-starch feedstuffs compared with starch-rich feedstuffs. The LS diets were supplemented with $350 \mathrm{~g} / \mathrm{d}$ of a mineral premix $(5.5 \% \mathrm{P}, 27 \% \mathrm{Ca}$, and $4 \% \mathrm{Mg}$ ) and the HS diets were also supplemented with $100 \mathrm{~g} / \mathrm{d}$ of calcium carbonate to meet mineral requirements (INRA, 1989) and compensate for the lower Ca content of starch-rich feedstuffs.

The 6 concentrates were pelleted with soybean meal and urea to facilitate the TMR distribution. Corn silage (MONTOP variety, NK Semences, Syngenta Seeds, Saint-Sauveur, France) was used as the sole forage source. It was harvested as whole-crop silage on a single day (September 25, 2008). A Claas 870 forage harvester (Claas, Harsewinkel, Germany) was used to obtain silage chopped at a theoretical chop length of $17 \mathrm{~mm}$. The composition of the 6 diets is given in Table 1.

The amount of CRDM of the 6 experimental concentrates was determined using the standardized nylon bag technique developed in France as described by Michalet-Doreau et al. (1987) and Vérité et al. (1990). Briefly, 3 rumen-fistulated dry cows $(\mathrm{BW}, 650 \mathrm{~kg})$ were fed with $7 \mathrm{~kg}$ of natural grassland hay and concentrate DM (70:30) in 2 equal meals at 0800 and $1730 \mathrm{~h}$. About $3 \mathrm{~g}$ of each concentrate ground through a $0.8-\mathrm{mm}$ screen was inserted into the nylon bag. Bags were introduced simultaneously into the rumen of the 3 cows and incubated for $4 \mathrm{~h}$. Adjustments for variations in microbial activity were established by reference to a standard sample of dehydrated lucerne (Vérité et al., 1990).

Diets were fed in 2 equal-sized meals per day at 0800 and $1800 \mathrm{~h}$. The amount of feed offered was individually adjusted to $100 \%$ of the DM ingested during the preexperimental period when cows were fed a diet based on corn silage with the proportion of forage decreasing progressively from 50 to $40 \%$. Cows had free access to the mangers from 0800 to $1130 \mathrm{~h}$ and from 1700 to $0200 \mathrm{~h}$ to reveal prominent between-diet differences in ruminal fermentation kinetics and to avoid creating small meals during the day.

\section{Sampling Schedule and Procedure}

Feeds and Orts. Voluntary DMI was recorded daily for each cow throughout the experiment. Orts were collected and weighed daily before the morning feeding. To adjust the proportion of corn silage in the diet and to calculate DMI, the DM content of concentrates $\left(80^{\circ} \mathrm{C}\right.$,
$48 \mathrm{~h}$ ) was determined weekly, whereas the DM content of corn silage and orts were determined every day. To determine the chemical composition of the corn silage, a representative sample of the whole silo was produced by sampling $1 \mathrm{~kg}$ weekly. Samples were kept frozen and pooled at the end of the experiment. Half of the sample was freeze-dried before proximal analyses and half was used to determine the fermentative profile of the silo. Weekly samples of concentrates were also pooled over the whole experimental period for proximal analyses. To determine particle size distribution, $500 \mathrm{~g}$ of corn silage was collected daily, stored at $4^{\circ} \mathrm{C}$, and pooled at the end of each 14-d experimental period. Particle size distribution was measured using the 2 different procedures [Penn State Particle Separator (PSPS) or Oscillating sieve shaker] described by Lechartier and Peyraud (2010).

Chewing Activity. Chewing activity was measured concurrently with feeding behavior. Feeding behavior was monitored by continuously weighing the manger. For measurements to be recorded, the weight of the manger had to be stabilized for $44 \mathrm{~ms}$. The total DMI and pattern of intake during the access time to the manger were recorded. On d 11 to 14 , the cows were equipped with a small balloon filled with foam rubber placed in the submandibular space and connected to a pressure transducer to measure jaw movements. An eating period was defined as a period during which jaw movements were recorded simultaneously to a decrease in the weight of the manger. A rumination period was defined as a period during which jaw movements were recorded without a simultaneous decrease in the weight of the manger. Average time spent eating or ruminating per kilogram of DM or forage NDF (FNDF) intake was calculated by dividing the total daily time of each activity (eating or ruminating) by the mean daily DMI or FNDF intake of the measurement days, respectively.

Ruminal $p H$ and Fermentation. Rumen fluid was sampled $(50 \mathrm{~mL})$ from the ventral sac at 0800 (before the meal), 0830, 0900, 0930, 1000, 1030, 1100, 1130, $1200,1300,1400,1500,1600$ and $1700 \mathrm{~h}$ on d13. At each sampling time, $\mathrm{pH}$ was measured immediately and the samples were strained through 6 layers of cheesecloth. For VFA analysis, a second 4-mL sample was mixed with $0.4 \mathrm{~mL}$ of $5 \%$ (wt/vol) orthophosphoric acid. For lactate analysis, $10 \mathrm{~mL}$ of ruminal fluid was sampled at 0800, 0900, 1000, 1100, 1200, 1300, 1400, 1500, 1600, and $1700 \mathrm{~h}$ without preservative. The samples were stored at $-20^{\circ} \mathrm{C}$. For $\mathrm{NH}_{3}$ analysis, $4 \mathrm{~mL}$ of strained rumen fluid were mixed with $4 \mathrm{~mL}$ of $20 \%$ (wt/vol) $\mathrm{NaCl}$.

Rumen Liquid Passage Rate. To determine the fractional outflow rate of liquid and rumen liquid volume, all cows were pulse-dosed through the rumen 
Table 1. Composition of the total mixed diets (DM basis)

\begin{tabular}{|c|c|c|c|c|c|c|}
\hline \multirow[b]{2}{*}{ Item } & \multicolumn{6}{|c|}{ Treatment $^{1}$} \\
\hline & S-LS & M-LS & R-LS & S-HS & M-HS & R-HS \\
\hline \multicolumn{7}{|l|}{ Ingredient (\%) } \\
\hline Corn silage & 39.9 & 39.7 & 39.8 & 39.6 & 39.6 & 39.6 \\
\hline Soybean hulls & 23.5 & 5.9 & - & - & - & - \\
\hline Ground wheat straw & - & - & - & 6.8 & 5.7 & 5.9 \\
\hline Corn & 11.2 & 7.9 & - & 37.1 & 23.8 & 9.9 \\
\hline Wheat & - & - & 2.0 & - & 14.6 & 29.7 \\
\hline Wheat bran & 2.7 & 8.6 & 15.6 & - & 1.5 & - \\
\hline Citrus pulp & 3.8 & 13.7 & 24.5 & - & - & - \\
\hline Beet pulp & 5.9 & 11.3 & 3.9 & - & - & - \\
\hline Soybean meal & 1.9 & 1.0 & 2.0 & 2.9 & 1.4 & 2.0 \\
\hline Formaldehyde-treated soybean meal & 6.7 & 7.4 & 7.8 & 8.7 & 8.6 & 8.3 \\
\hline Cane molasses & 1.6 & 1.6 & 1.6 & 1.6 & 1.6 & 1.6 \\
\hline Soybean oil & 0.4 & 0.4 & 0.4 & 0.4 & 0.4 & 0.4 \\
\hline Urea & 1.1 & 1.3 & 1.1 & 1.1 & 1.1 & 1.0 \\
\hline Mineral-vitamin premix ${ }^{2}$ & 1.4 & 1.4 & 1.4 & 1.4 & 1.4 & 1.4 \\
\hline Calcium carbonate & - & - & - & 0.4 & 0.4 & 0.4 \\
\hline \multicolumn{7}{|l|}{ Chemical composition (\%) } \\
\hline $\mathrm{DM}$ & 58.7 & 58.9 & 58.8 & 58.7 & 58.6 & 58.6 \\
\hline $\mathrm{OM}$ & 94.3 & 93.8 & 93.4 & 94.6 & 94.6 & 94.7 \\
\hline $\mathrm{CP}(\mathrm{N} \times 6.25)$ & 15.5 & 16.6 & 17.9 & 17.0 & 15.9 & 16.3 \\
\hline NDF & 38.8 & 33.4 & 30.5 & 25.0 & 24.8 & 25.4 \\
\hline $\mathrm{ADF}$ & 23.6 & 18.3 & 16.1 & 13.1 & 12.5 & 13.0 \\
\hline $\mathrm{ADL}^{3}$ & 1.5 & 1.7 & 1.8 & 1.1 & 1.1 & 1.3 \\
\hline $\mathrm{WICW}^{4}$ & 44.6 & 40.8 & 38.1 & 29.5 & 29.2 & 29.6 \\
\hline Starch & 25.6 & 26.5 & 22.8 & 40.9 & 42.3 & 40.9 \\
\hline Starch from corn silage & 13.9 & 13.8 & 13.8 & 13.8 & 13.8 & 13.8 \\
\hline $\mathrm{CRDM}^{5}$ from INRA-AFZ (2004) & 17.5 & 22.6 & 27.4 & 18.2 & 23.4 & 28.2 \\
\hline CRDM from measurements & 20.2 & 26.2 & 28.5 & 23.7 & 25.5 & 29.9 \\
\hline FNDF $^{6}$ & 15.0 & 14.9 & 14.9 & 14.8 & 14.9 & 14.9 \\
\hline \multicolumn{7}{|l|}{ Nutritional value } \\
\hline $\mathrm{NE}_{\mathrm{L}}(\mathrm{Mcal} / \mathrm{kg})$ & 1.61 & 1.69 & 1.72 & 1.70 & 1.75 & 1.73 \\
\hline $\mathrm{PDIE}^{7}(\mathrm{~g} / \mathrm{kg})$ & 91 & 94 & 97 & 96 & 92 & 91 \\
\hline $\mathrm{PDIN}^{8}(\mathrm{~g} / \mathrm{kg})$ & 100 & 106 & 115 & 110 & 102 & 103 \\
\hline
\end{tabular}

${ }^{1} \mathrm{~S}, \mathrm{M}$, and $\mathrm{R}$ = slowly, moderately, and rapidly degradable concentrate, respectively; LS and HS = low and high dietary starch content, respectively.

${ }^{2}$ Contained $52 \%$ calcium carbonate, $23 \%$ dicalcium phosphate, $10 \%$ calcium and magnesium phosphate, $9 \%$ cane molasses, $6 \%$ magnesia oxide, $600 \mathrm{KIU}$ of vitamin $\mathrm{A} / \mathrm{kg}, 80 \mathrm{KIU}$ of vitamin $\mathrm{D}_{3} / \mathrm{kg}, 1,500 \mathrm{mg}$ of vitamin $\mathrm{E} / \mathrm{kg}, 4,000 \mathrm{mg}$ of $\mathrm{Zn} / \mathrm{kg}, 4,000 \mathrm{mg}$ of $\mathrm{Mn} / \mathrm{kg}, 1,000 \mathrm{mg}$ of $\mathrm{Cu} / \mathrm{kg}$ (sulfate and chelate), $80 \mathrm{mg}$ of I/ $\mathrm{kg}, 20 \mathrm{mg}$ of $\mathrm{Co} / \mathrm{kg}$, and $20 \mathrm{mg} / \mathrm{kg}$ of Se.

${ }^{3}$ Acid detergent lignins.

${ }^{4}$ Water-insoluble cell walls.

${ }^{5}$ Rapidly degradable DM from concentrate.

${ }^{6} \mathrm{NDF}$ from forage.

${ }^{7}$ Digestible protein in the small intestine, supplied by microbial protein from rumen-fermented OM (INRA, 1989).

${ }^{8}$ Digestible protein in the small intestine, supplied by microbial protein from RDP (INRA, 1989).

fistulae on $\mathrm{d} 11$ at $1130 \mathrm{~h}$ with $50 \mathrm{~g}$ of $\mathrm{LiCo}(\mathrm{II}) \mathrm{EDTA}$ (Udén et al., 1980) diluted in $2 \mathrm{~L}$ of water. Rumen fluid was then collected at 1330, 1530,1800, and $2100 \mathrm{~h}$ on $\mathrm{d} 11$ and at 0700 and $1400 \mathrm{~h}$ on d 12. At each sampling time, $10 \mathrm{~mL}$ of strained rumen fluid was centrifuged at $4,000 \times g$, for $15 \mathrm{~min}$ at $4^{\circ} \mathrm{C}$ and frozen at $-20^{\circ} \mathrm{C}$ for $\mathrm{Co}$ analyses. Fractional liquid outflow rate was calculated from the declining slope of the natural logarithm of Co concentration over time, after dosing. Rumen liquid volume was calculated by dividing the quantity of $\mathrm{Co}$ dosed in the rumen by the calculated concentration at zero time. Rumen liquid outflow was calculated by multiplying rumen liquid volume and fractional outflow rate.

Cellulolytic Activity. Disappearance of soybean hulls DM incubated in nylon bags was used as an index of the fibrolytic activity of the rumen. On d 14, $3 \mathrm{~g}$ of soybean hulls ground through a $0.8-\mathrm{mm}$ screen were inserted into the nylon bag $(6 \times 11 \mathrm{~cm}$, pore size $=$ $0.050 \mathrm{~mm})$. The bags were introduced into the rumen before the morning meal $(0800 \mathrm{~h})$ and incubated for $24 \mathrm{~h}$. After removal, the bags were washed with cold 
water in a washing machine (3 times for periods of $5 \mathrm{~min})$ and then oven-dried $\left(48 \mathrm{~h}, 80^{\circ} \mathrm{C}\right)$. Two bags were used per cow.

Milk Production and Composition. Milk production was recorded at each milking. Milk protein and fat content were determined by infrared analysis (Milkoscan, Foss Electric, Hillerød, Denmark) on individual samples collected on 8 successive milkings each week. On d 13, $100 \mathrm{~mL}$ of milk was sampled at the morning milking for analysis of fatty acids composition. Milk fatty acids were analyzed according to Apper-Bossard et al. (2006).

\section{Chemical Analyses}

Analyses were performed on mean dry samples of feeds, feed refusals, and feces. All samples were ground with a 3-blade knife mill (Retsch GmbH, Haan, Germany) through a $0.8-\mathrm{mm}$ screen. Organic matter content was determined by ashing at $550^{\circ} \mathrm{C}$ for $6 \mathrm{~h}$. Nitrogen content was obtained by the Kjeldahl method. The NDF, ADF, and acid detergent lignins were analyzed on a Fibersac M extraction unit (Ankom Technology, Fairport, NY) after hydrolysis of starch with $\alpha$-amylase (Ankom) as described in Le Liboux and Peyraud (1999). Starch content was determined by the Ewers polarimetric method (Association Française de Normalisation, 1985).

Total VFA concentration and VFA profile were determined by GC as described by Hurtaud et al. (1993) using a gas liquid chromatograph (Varian SA, Les Ulis, France) on a column (1.5-m long $\times 2$-mm i.d.) packed with 80/100 mesh Chromosorb 101 (Stabilwax DA, Rostek France, Lisse, France) with nitrogen as the carrier gas. Ammonia in the rumen content was determined by the method described in Le Liboux and Peyraud (1999). The D- and L-lactate concentrations were determined using an enzymatic method (ENZYTEC D-/L-Lactic acid, Scil Diagnostics GmbH, Viernheim, Germany) fitted on a multi-parameter analyzer (KONE Instruments Corporation, Espoo, Finland). For Co analysis, centrifuged rumen fluid was pumped directly and analyzed by flame atomic spectrometry (Varian, Varian Australia Pty Ltd., Mulgrave, Victoria, Australia).

\section{Calculations}

Given that the spot values of ruminal $\mathrm{pH}$, total VFA concentration, molar proportions of the different VFA, and $\mathrm{NH}_{3}$ concentration were separated by half an hour at the beginning of the kinetics and by an hour at the end of the kinetics, the mean values of these parameters were calculated by weighting each spot value by the time separating 2 successive samplings ( $0.5 \mathrm{~h}$ from 0800 to $1130 \mathrm{~h}$ and $1 \mathrm{~h}$ from 1200 to $1700 \mathrm{~h}$ ).
Analysis of the $\mathrm{pH}$ curves was performed as described by Lechartier and Peyraud (2010) by fitting the timeevolution of $\mathrm{pH}$ to a third-degree polynomial function:

$$
\mathrm{pH}_{\mathrm{t}}=a \mathrm{t}^{3}+\mathrm{bt}^{2}+\mathrm{ct}+\mathrm{d},
$$

where $\mathrm{t}=$ time post-feeding and $\mathrm{pH}_{\mathrm{t}}=$ value of the ruminal $\mathrm{pH}$ at $\mathrm{t}$ hours post-feeding. The 4 coefficients $\mathrm{a}, \mathrm{b}, \mathrm{c}$, and d were used to calculate the initial $\mathrm{pH}$ at $0800 \mathrm{~h}$ (just before the beginning of the morning meal); the rate of $\mathrm{pH}$ drop at $0800 \mathrm{~h}$ (initial rate of $\mathrm{pH}$ drop); the post-feeding amplitude of $\mathrm{pH}$ perturbations $(\mathrm{pH}$ range), calculated by the difference between initial $\mathrm{pH}$ and minimal $\mathrm{pH}$ at a time point when the first derivative is nil; the time during which $\mathrm{pH}$ was below 6.0 and 5.8; the area under the $\mathrm{pH} 6.0$ and 5.8 curves; and the rate of $\mathrm{pH}$ increase at $1700 \mathrm{~h}$ (final rate of $\mathrm{pH}$ increase). The kinetic parameters of VFA were analyzed in the same way to calculate the initial rate of VFA increase and the VFA range.

\section{Statistical Analyses}

All data were analyzed as a $6 \times 6$ Latin square with a factorial arrangement of treatments using PROC MIXED of SAS (SAS Institute, 1999). The model included treatments (starch level and CRDM), the interaction between starch level and CRDM, and period as fixed effects, and cow as random effect. All means presented are least squares means. The sum of squares of the CRDM and starch level $\times$ CRDM effects were further partitioned into comparisons with a single degree of freedom to provide linear and quadratic effects of CRDM and its interaction with starch level using the orthogonal polynomial method (Gill, 1978). As the quadratic effects of starch level $\times$ CRDM were never significant, the probabilities of this contrast are not presented in the tables. Pearson correlation coefficients between ruminal fermentation parameters were estimated using the CORR procedure of SAS. Effects of the factors were declared significant at $P<0.05$ unless stated otherwise.

\section{RESULTS}

\section{Chemical and Physical Composition of the Diets}

The DM of corn silage averaged $32.8 \%$. The silage was well preserved, with a mean $\mathrm{pH}$ averaging 3.7. Lactic acid, acetic acid, and propionic acid concentrations were $7.5,1.28$, and $0.004 \% \mathrm{DM}$, respectively. On a DM basis, corn silage contained $34.8 \%$ starch, $37.5 \%$ NDF, and $7.2 \% \mathrm{CP}$.

Starch content averaged 25.0 and $41.4 \%$ of DM for LS and HS diets, respectively (Table 1). The starch 
Table 2. Particle size distribution of corn silage (DM basis)

\begin{tabular}{lc}
\hline Item & $\begin{array}{c}\text { Retention on sieves } \\
(\% \mathrm{DM})\end{array}$ \\
\hline Penn State Particle Separator & \\
$19 \mathrm{~mm}$ & 8.4 \\
$8 \mathrm{~mm}$ & 72.4 \\
$1.18 \mathrm{~mm}$ & 17.3 \\
Pan & 1.9 \\
pef $_{8.0}{ }^{2}$ & 81.0 \\
pef $_{1.18}{ }^{2}$ & 98.0 \\
peNDF $_{8}{ }^{2}$ & 30.3 \\
peNDF $_{1.18}{ }^{2}$ & 36.8 \\
Oscillating sieve shaker $^{3}$ & \\
$20 \mathrm{~mm}$ & 3.7 \\
$10 \mathrm{~mm}$ & 29.0 \\
$4 \mathrm{~mm}$ & 45.3 \\
$2 \mathrm{~mm}$ & 13.8 \\
$1 \mathrm{~mm}$ & 5.7 \\
$<1 \mathrm{~mm}$ & 2.5 \\
$>4 \mathrm{~mm}$ & 78.0 \\
$>2 \mathrm{~mm}$ & 91.8 \\
FNDF $_{4}^{4}$ & 29.3 \\
FNDF $_{2}^{4}$ & 34.4 \\
\hline
\end{tabular}

${ }^{1}$ Particle size distribution of corn silage measured using the Penn State Particle Separator (Kononoff et al., 2003).

${ }^{2}$ pef $_{8.0}$ and pef $_{1.18}=$ physical effectiveness factor determined as the proportion of particles retained on 2 sieves $(19$ and $8 \mathrm{~mm})$ and on 3 sieves $(19,8$, and $1.18 \mathrm{~mm})$, respectively; $\operatorname{peNDF}_{8.0}$ and $\mathrm{peNDF}_{1.18}=$ physically effective NDF determined as NDF content of corn silage multiplied by pef 8.0 and pef $_{1.18}$, rescpectively.

${ }^{3}$ Particle size distribution of corn silage measured using a manual shaker equipped with 2 sieves (20 and $10 \mathrm{~mm}$ ) and a vertical oscillating sieve shaker equipped with a stack of sieves arranged in descending mesh size $(4,2,1$, and $0.5 \mathrm{~mm})$.

${ }^{4} \mathrm{FNDF}_{4}$ and $\mathrm{FNDF}_{2}=\mathrm{NDF}$ content of corn silage multiplied by $>4$ $\mathrm{mm}$ and $>2 \mathrm{~mm}$, respectively, where $>4 \mathrm{~mm}$ and $>2 \mathrm{~mm}=$ cumulative proportion of particles retained on a $4-\mathrm{mm}$ and a 2 -mm sieve, respectively.

concentration from corn silage was $13.8 \%$ of DM for the 6 TMR, and starch concentrations provided by the experimental concentrates were 11.1 and $27.6 \%$ of DM for the LS and HS diets, respectively. The CRDM increased from 17.8 to $27.8 \%$ of DM between $\mathrm{S}$ and $\mathrm{R}$ diets and was numerically identical between LS and HS diets (22.5 and $23.3 \%$ of DM for LS and HS diets, respectively). The NDF content averaged 34.2 and $25.1 \%$ of DM for LS and HS diets, respectively. The NDF content did not vary among HS diets but decreased between S-LS and R-LS diets.

The cumulative proportion of DM retained on the $8-\mathrm{mm}$ sieve of the PSPS was numerically close to the cumulative proportion of DM retained on the 4-mm sieve of the oscillating sieve shaker (PSPS: $81.0 \%$ vs. oscillating sieve shaker: $78.0 \%$; Table 2). The cumulative proportion of particles retained was numerically higher on the 1.18-mm sieve of the PSPS than on the 2-mm sieve of the oscillating sieve shaker (PSPS: $98.0 \%$ vs. oscillating sieve shaker: $91.8 \%$ ).
Diets were formulated from INRA feed tables to keep constant CP content. However, R-LS and S-HS diets and, to a lesser extent, M-LS diets had higher CP content than expected. These differences probably originated from unexpected variations in the composition of ingredients used to produce the experimental concentrates. However, the content of MP per MJ of $\mathrm{NE}_{\mathrm{L}}$ was rather constant [53 to $57 \mathrm{~g}$ of digestible protein in the small intestine, supplied by microbial protein from rumen-fermented OM (PDIE) per $\mathrm{MJ}$ of $\mathrm{NE}_{\mathrm{L}}$ ] among diets. All diets had an excess of degradable $\mathrm{N}$ and this is reflected by a high ammonia concentration in the rumen. The measured CRDM using the in sacco procedure were slightly higher than the book values (Table $1)$, but were highly correlated to those $(r=0.95)$.

\section{Intake}

Table 3 reports daily intake data. When feeding HS diets, total DMI, NDF intake, and FNDF intake decreased $(P<0.001)$ and CRDM intake decreased by $0.4 \mathrm{~kg} / \mathrm{d}(P<0.01)$, whereas $\mathrm{OM}$ intake tended to decrease $(P=0.10)$ and starch intake increased $(+3.5$ $\mathrm{kg} / \mathrm{d}, P<0.001)$.

When increasing CRDM, total DMI and intake of OM, FNDF, and CRDM decreased linearly $(P<$ 0.001). Starch intake also decreased, but the effect was less pronounced between $\mathrm{L}$ and $\mathrm{M}$ diets than between $\mathrm{M}$ and $\mathrm{R}$ diets. Intakes of NDF and ADF also decreased linearly with increasing CRDM $(P<0.001)$, the rate of decrease being greater under LS diets than HS diets (interaction $\mathrm{CRDM} \times$ starch, $P<0.001$ ). Increasing CRDM led to a decrease in CP intake under HS diets but did not vary under LS diets.

\section{Chewing Activity}

Table 4 reports data on feeding behavior. The CRDM had no effect on time spent eating and ruminating, and total time $(\mathrm{min} / \mathrm{d})$ spent chewing $(P<0.10)$. Feeding HS diets decreased eating time $(P<0.02)$ but ruminating and total chewing times remained unaffected. Time spent eating, ruminating, and chewing per kilogram of DMI and per kilogram of FNDF increased linearly with increasing CRDM, but these effects were moderate. Total chewing time per kilogram of DMI increased by 3.4 min from $\mathrm{S}$ to $\mathrm{R}$ diets. Feeding HS diets did not affect chewing time per unit of DMI or FNDF.

\section{Ruminal Fermentation}

Data on ruminal fermentation patterns are reported in Table5, Figure 1, Figure 2, and Figure 3. The quality 
Table 3. Effects of dietary contents of rapidly degradable DM from concentrate (CRDM) and starch (St) on intake of DM, OM, cell wall components, St, CP, and CRDM

\begin{tabular}{|c|c|c|c|c|c|c|c|c|c|c|c|}
\hline \multirow{2}{*}{$\begin{array}{l}\text { Intake } \\
(\mathrm{kg} / \mathrm{d})\end{array}$} & \multirow{2}{*}{\multicolumn{6}{|c|}{ Treatment $^{1}$}} & \multirow{2}{*}{ SEM } & \multicolumn{4}{|c|}{$P$-value ${ }^{2}$} \\
\hline & & & & & & & & \multicolumn{2}{|c|}{ CRDM } & St & $\frac{\mathrm{CRDM} \times \mathrm{St}}{\mathrm{L}}$ \\
\hline $\mathrm{DM}$ & 24.0 & 22.4 & 22.0 & 23.4 & 21.6 & 20.6 & 0.99 & $<0.001$ & 0.25 & 0.04 & 0.42 \\
\hline As concentrate & 14.4 & 13.5 & 13.3 & 14.2 & 13.0 & 12.4 & 0.59 & $<0.001$ & 0.28 & 0.06 & 0.41 \\
\hline As corn silage & 9.6 & 8.9 & 8.8 & 9.3 & 8.6 & 8.2 & 0.39 & $<0.001$ & 0.23 & 0.03 & 0.45 \\
\hline $\mathrm{ADF}$ & 5.7 & 4.1 & 3.5 & 3.0 & 2.6 & 2.5 & 0.17 & $<0.001$ & 0.002 & $<0.001$ & $<0.001$ \\
\hline St & 6.1 & 5.9 & 5.0 & 9.7 & 9.3 & 8.6 & 0.33 & $<0.001$ & 0.05 & $<0.001$ & 0.80 \\
\hline $\mathrm{CP}$ & 3.8 & 3.8 & 4.0 & 4.0 & 3.6 & 3.5 & 0.17 & 0.07 & 0.06 & 0.02 & $<0.001$ \\
\hline $\mathrm{FNDF}^{3}$ & 3.6 & 3.4 & 3.3 & 3.5 & 3.2 & 3.1 & 0.15 & $<0.001$ & 0.29 & 0.04 & 0.53 \\
\hline CRDM & 4.5 & 5.6 & 6.3 & 4.3 & 5.1 & 5.8 & 0.25 & $<0.001$ & 0.47 & 0.01 & 0.35 \\
\hline
\end{tabular}

${ }^{1} \mathrm{~S}, \mathrm{M}$, and $\mathrm{R}=$ slowly, moderately, and rapidly degradable concentrate, respectively; LS and HS = low and high dietary starch content, respectively.

${ }^{2} \mathrm{~L}=$ linear; $\mathrm{Q}=$ quadratic.

${ }^{3} \mathrm{NDF}$ from forage.

of adjustments was rather good. For $\mathrm{pH}$, the coefficient of determination $\left(\mathrm{r}^{2}\right)$ was higher than 0.80 for 23 out of 36 kinetics and $\mathrm{r}^{2}$ was below 0.68 for only 4 kinetics, corresponding to cows showing a rather flat curve.

The time during which $\mathrm{pH}$ was below 6.0 was highly correlated to the mean ruminal $\mathrm{pH}$ and the relationship did not differ between the treatments:

$$
\text { Time } \mathrm{pH}<6.0(\mathrm{~h})=74.9-11.6 \times \mathrm{Mean} \mathrm{pH}
$$

$$
\left(\mathrm{n}=36 ; \mathrm{r}^{2}=0.87 ; \mathrm{RSD}=0.83\right) .
$$

The area under the $\mathrm{pH} 6.0$ curve was also highly correlated to the mean ruminal $\mathrm{pH}\left(\mathrm{r}^{2}=0.85\right)$ but the initial rate of $\mathrm{pH}$ drop and the $\mathrm{pH}$ range were not correlated to mean $\mathrm{pH}(P>0.10)$.

Mean ruminal $\mathrm{pH}$ and initial $\mathrm{pH}$ before the morning meal were higher when feeding HS diets compared with LS diets, although a strong $\mathrm{CRDM} \times$ starch interaction $(P<0.02)$ existed. Mean and initial $\mathrm{pH}$ did not differ between HS and LS diets at low-level CRDM, but when CRDM increased, mean $\mathrm{pH}$ and initial $\mathrm{pH}$ increased under HS diets but decreased under LS diets.

The time during which $\mathrm{pH}$ was below 6.0 was less under HS diets $(P<0.01)$, but a strong CRDM $\times$ starch interaction $(P<0.01)$ existed. It increased with increasing CRDM under LS diets but decreased under

Table 4. Effects of dietary contents of rapidly degradable DM from concentrate (CRDM) and starch (St) on feeding behavior

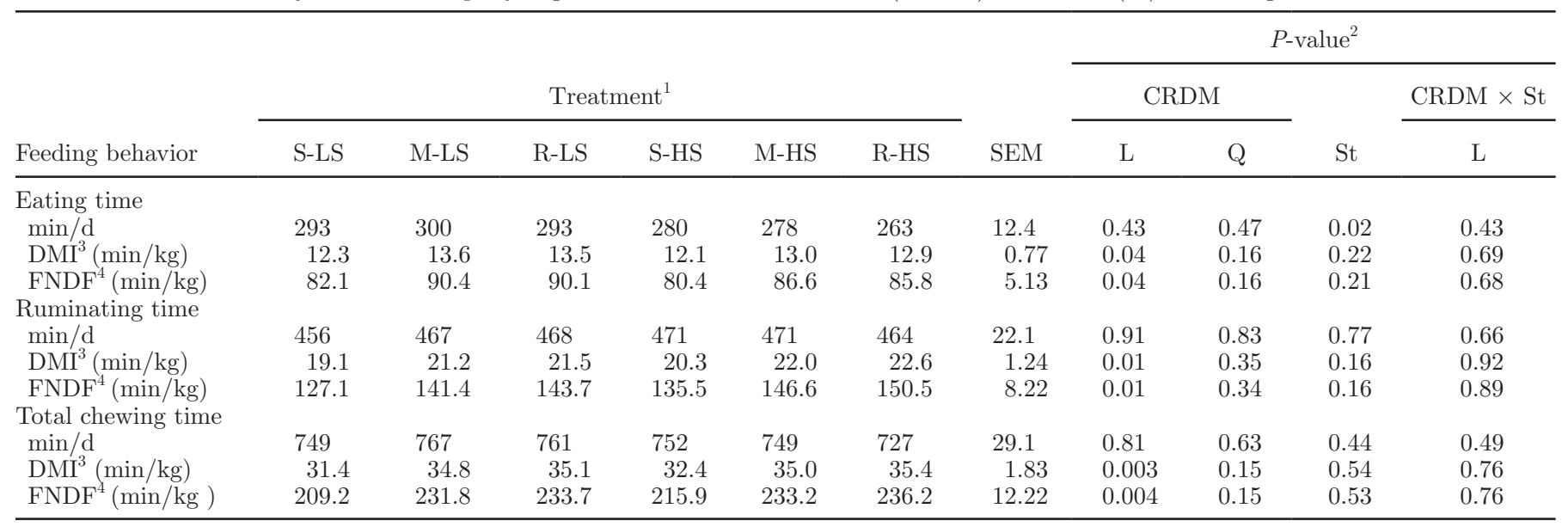

${ }^{1} \mathrm{~S}, \mathrm{M}$, and $\mathrm{R}=$ slowly, moderately, and rapidly degradable concentrate, respectively; LS and HS = low and high dietary starch content, respectively.

${ }^{2} \mathrm{~L}=$ linear; $\mathrm{Q}=$ quadratic.

${ }^{3}$ Related to DMI for the same days of feeding behavior recordings.

${ }^{4} \mathrm{NDF}$ from forage; related to NDF from forage (FNDF) intake for the same days of feeding behavior recordings. 
Table 5. Effects of dietary contents of rapidly degradable DM from concentrate (CRDM) and starch (St) on ruminal pH and fermentation characteristics of dairy cows throughout a feeding cycle

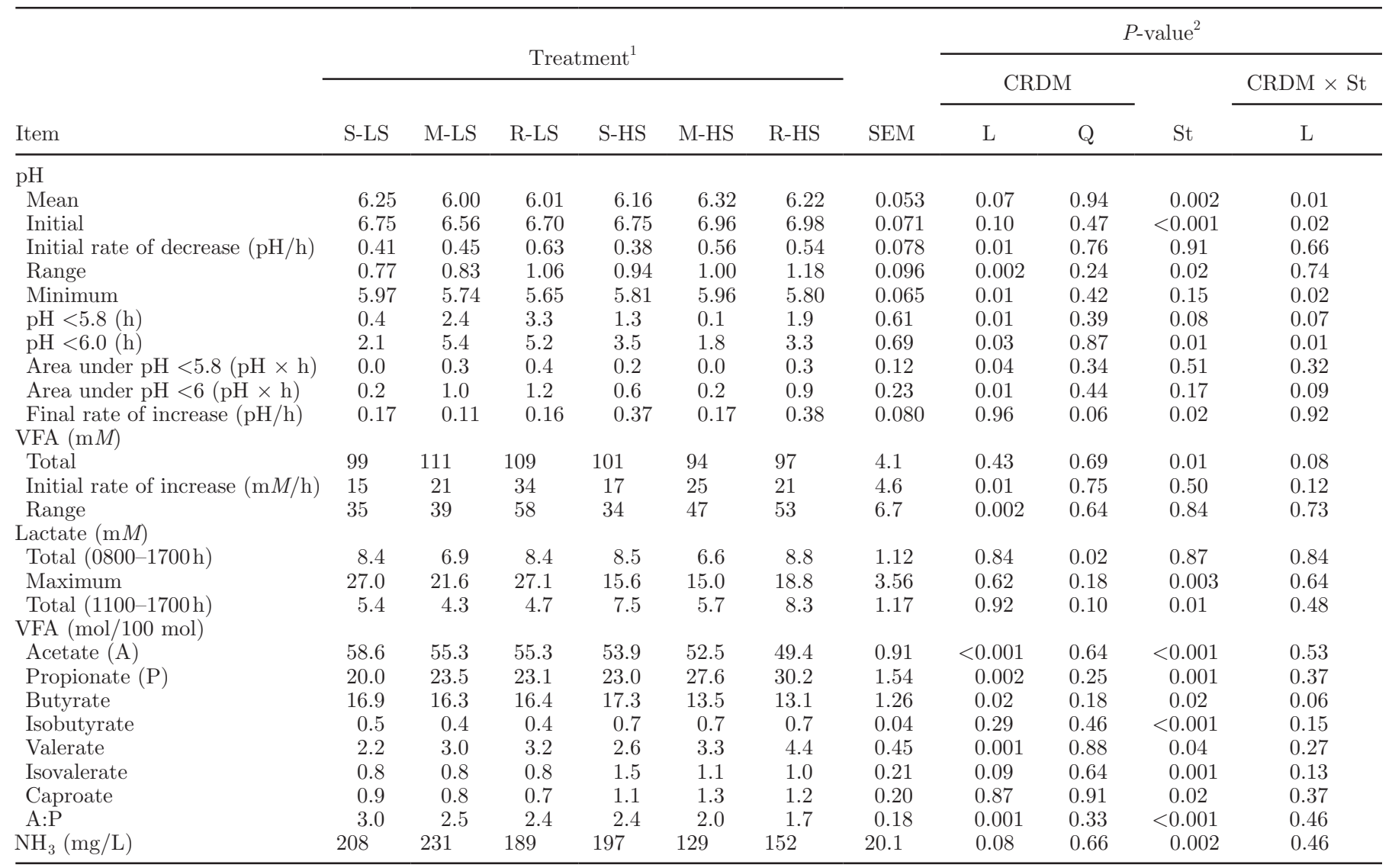

${ }^{1} \mathrm{~S}, \mathrm{M}$, and $\mathrm{R}=$ slowly, moderately, and rapidly degradable concentrate, respectively; LS and HS = low and high dietary starch content, respectively.

${ }^{2} \mathrm{~L}=$ linear; $\mathrm{Q}=$ quadratic.

HS diets. Similar trends were observed for the time during which $\mathrm{pH}$ was below 5.8.

Mean VFA concentrations were correlated to mean $\mathrm{pH}$ :

$$
\begin{gathered}
\text { Mean } \mathrm{pH}=7.45-0.0127 \times \text { Mean VFA }(\mathrm{m} M) \\
\left(\mathrm{n}=36 ; \mathrm{r}^{2}=0.60 ; \mathrm{RSD}=0.115\right)
\end{gathered}
$$

and the relationship did not differ between HS and LS diets.

The initial rate of $\mathrm{pH}$ decrease increased with increasing CRDM, and did not vary between HS and LS diets. The final rate of $\mathrm{pH}$ increase was higher under HS diets $(P<0.02)$ and peaked down at the moderate level of CRDM. The range of VFA concentrations and $\mathrm{pH}$ increased linearly with increasing $\mathrm{CRDM}(P<$ $0.002 ;+21 \mathrm{~m} M$ and +0.26 unit for VFA concentration and $\mathrm{pH}$ for $10 \%$ CRDM increase, respectively). Feeding HS diets increased the $\mathrm{pH}$ range without modifying the
VFA range. Finally, the range of $\mathrm{pH}$ variation was lower under LS diets than HS diets for a similar postprandial variation of VFA concentration:

$$
\begin{gathered}
\mathrm{pH} \text { range }=0.42+0.0105 \times \text { VFA range }(\mathrm{m} M) \\
+0.14(\text { for HS diets }) \\
\left(\mathrm{n}=36 ; \mathrm{r}^{2}=0.48 ; \mathrm{RSD}=0.225\right) .
\end{gathered}
$$

No treatment effects existed on the ratio between Llactate and D-lactate, both enantiomers retaining similar concentrations. Consequently, Table 5 presents the sum of the 2 enantiomers. Feeding HS diets had no effect on mean lactate concentration. Lactate concentration showed a transient peak. Feeding HS diets decreased this peak ( 16.5 vs. $25.2 \mathrm{mM}$ for HS and LS diets, respectively; $P<0.004)$ but led to increased lactate concentrations in the second part of the kinetics (Figure 3; $P<0.01)$. The CRDM only moderately affected lactate 


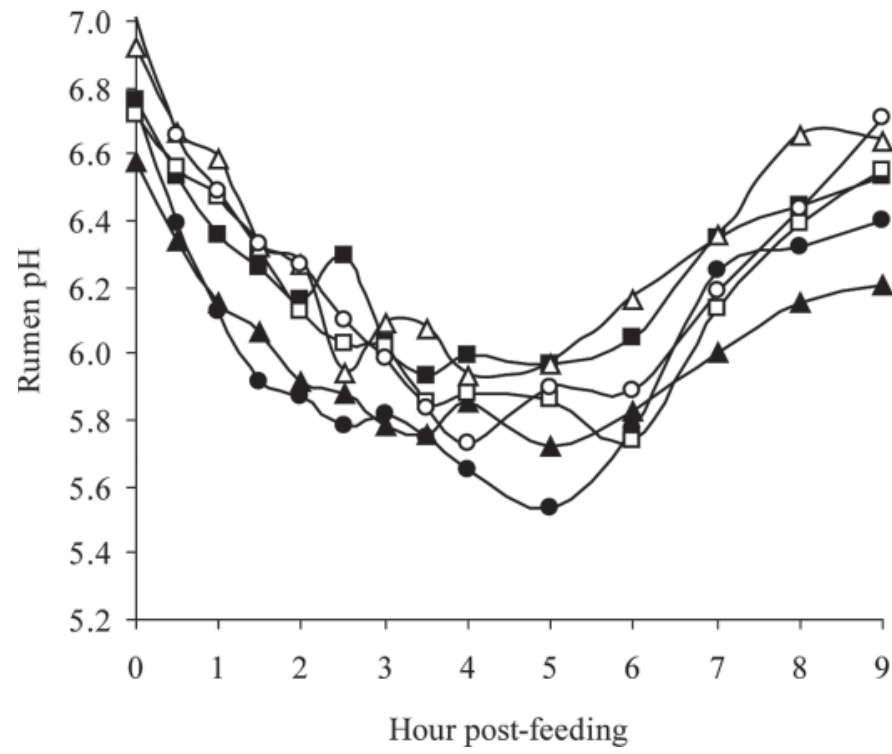

Figure 1. Post-feeding fluctuations in ruminal pH for diets differing in starch content and in rapidly degradable dry matter from concentrate. R-LS: ๑; M-LS: $\mathbf{\Delta}$; S-LS: $\mathbf{\square}$; R-HS: O; M-HS: $\Delta$; S-HS: $\square$. S, M, and R = slowly, moderately, and rapidly degradable concentrate, respectively; LS and HS = low and high dietary starch content, respectively.

concentration. The mean lactate concentration reached a minimum value for M-LS and M-HS diets.

Feeding HS diets increased the molar proportion of propionate and decreased the molar proportion of acetate and the acetate-to-propionate ratio $(P<0.001)$. It also increased molar proportions of valerate and caproate $(P<0.05)$. Feeding the HS diets with the low CRDM increased the molar proportion of butyrate, and HS diets fed with the medium and the high CRDM decreased the molar proportion of butyrate. Feeding HS diets increased the molar proportion of isobutyrate and isovalerate but decreased the ammonia concentration. Increasing CRDM linearly increased the molar proportion of propionate and valerate $(P<0.005)$, linearly decreased the molar proportion of acetate $(P<0.001)$, and linearly decreased the acetate-to-propionate ratio. Increasing CRDM linearly decreased the molar proportion of butyrate under the HS diet but not under the LS diet (interaction $\mathrm{CRDM} \times$ starch, $P<0.06$ ), and did not affect the molar proportion of caproate. Increasing CRDM also tended to decrease the molar proportion of isovalerate and ammonia $(P<0.10)$.

\section{Liquid Passage Rate and Fibrolytic Activity}

Table 6 reports passage rate and fibrolytic activity data. Feeding HS diets decreased fractional liquid outflow rate and daily liquid outflow $(P<0.002)$. Liquid outflow per kilogram of DMI averaged 8.9 and $10.3 \mathrm{~L}$ for HS and LS diets, respectively $(P<0.001)$. The HS diets did not affect rumen liquid volume. Increasing CRDM did not affect fractional liquid outflow rate, rumen liquid volume, or liquid outflow (L/d) but linearly increased liquid outflow per kilogram of DMI $(P<$ 0.01). The in sacco disappearance of soybean hulls DM decreased with increasing CRDM under HS diets but was unaffected under LS diets (interaction CRDM $\times$ starch, $P<0.05)$.

\section{Milk, Protein, and Fat Yield}

Table 7 reports milk production and composition data. Feeding HS diets decreased milk fat content and yield $(P<0.005)$ with no effect on milk protein content. Increasing CRDM decreased milk yield and milk protein yield under HS but not LS diets (interaction $\mathrm{CRDM} \times$ starch, $P<0.05)$. Increasing $\mathrm{CRDM}$ had no effect on milk protein content but linearly decreased milk fat yield $(P<0.05)$ and tended to decrease milk fat content $(P<0.11)$.

Feeding HS diets decreased the yield of all fatty acids, with the noticeable exception of the yield of trans-10 C18:1, which increased, and the yield of trans-11 C18:1 and Cis9, trans11 C18:2, which remained unaffected. Increasing CRDM decreased the yield of C14:0, C18:0, cis-9 C18:1, trans-11 C18:1, and C18:2 $(P<0.01)$, and tended to decrease the yield of monounsaturated fatty acids $(P<0.07)$. Increasing CRDM also decreased the

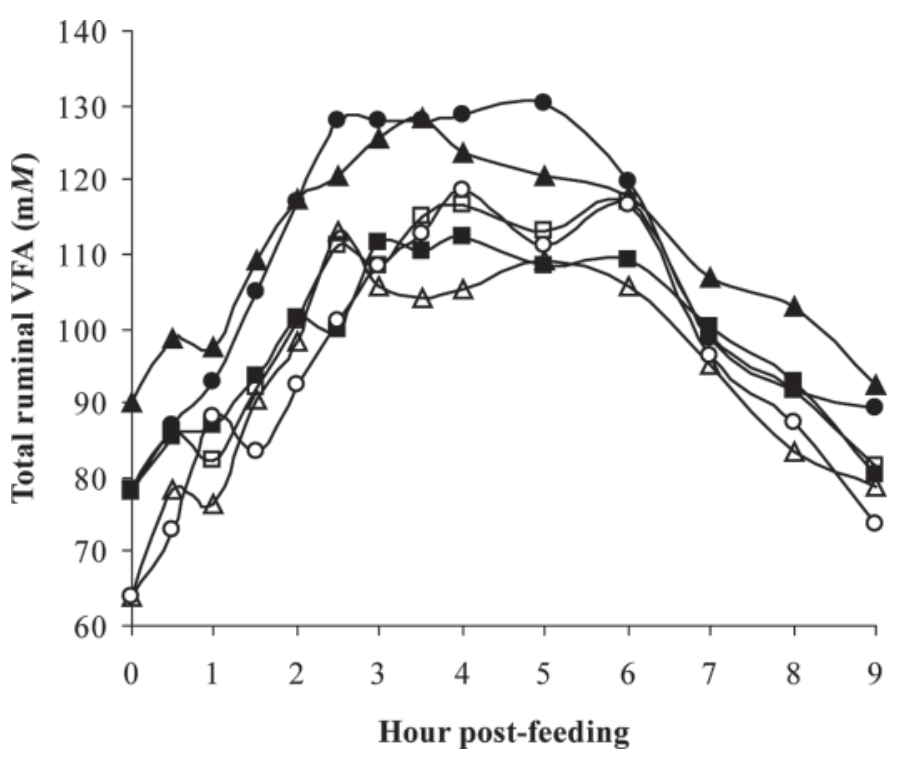

Figure 2. Post-feeding fluctuations in total ruminal VFA concentration for diets differing in starch content and in rapidly degradable DM from concentrate. R-LS: ๑; M-LS: $\mathbf{\Delta}$; S-LS: $\mathbf{~ ; ~ R - H S : ~ O ; ~ M - H S : ~}$ $\Delta$; S-HS: $\square$. S, M, and R = slowly, moderately, and rapidly degradable concentrate, respectively; LS and HS = low and high dietary starch content, respectively. 


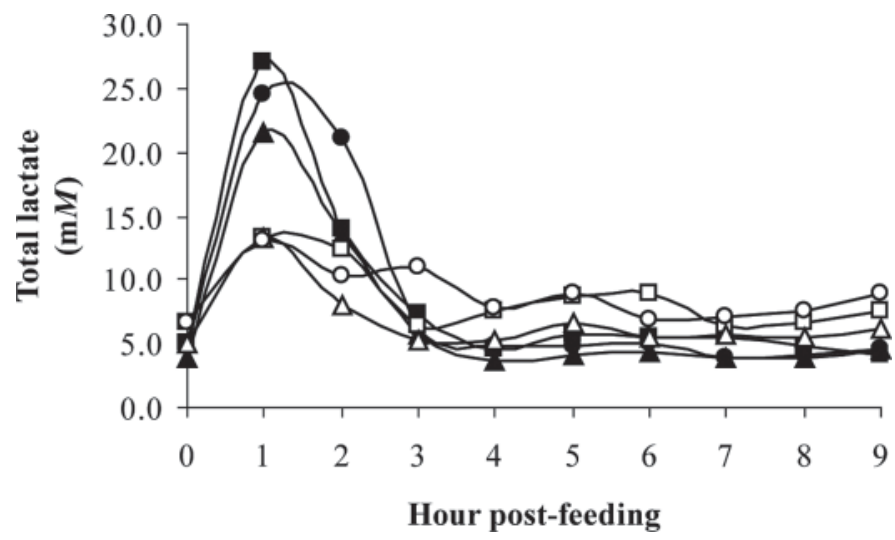

Figure 3. Post-feeding fluctuations in total ruminal lactate concentration for diets differing in starch content and in rapidly degradable DM from concentrate. R-LS: ๑; M-LS: $\mathbf{\Delta}$; S-LS: 口; R-HS: O; M-HS: $\Delta$; S-HS: $\square$. S, M and R = slowly, moderately, and rapidly degradable concentrate, respectively; LS and HS = low and high dietary starch content, respectively.

yield of polyunsaturated and cis-9, trans-11 C18:2, the rate of decrease being greater between $S$ and $M$ than between $\mathrm{M}$ and $\mathrm{R}$. Increasing CRDM did not affect the yield of short-chain fatty acids. Increasing CRDM tended to increase the yield of odd-chain fatty acids, although only under HS diets, and decreased the yield of $\mathrm{C} 18: 3$, the rate of decrease being stronger under LS than HS diets.

\section{DISCUSSION}

\section{Fibrousness of the Diets}

To prevent $\mathrm{pH}$ from dropping below the threshold values triggering SARA, the NRC (2001) recommends a minimum of $19 \%$ FNDF. Mertens (1997) recommended a minimum of $22 \%$ dietary physically effective $\mathrm{NDF}$ (peNDF) $)_{1.18}$ to maintain mean daily $\mathrm{pH}$ at 6.0.
The FNDF content of the diets used in the present study $(14.9 \%)$ and the peNDF $1.18(14.6 \%)$ did not reach these threshold values, which, as shown by Lechartier and Peyraud (2010), suggests they have low effectiveness and low buffering capacity. The low fat contents observed in some diets, especially under HS, when compared with the reference period (milk fat content $=33.9 \mathrm{~g} / \mathrm{kg}$ ) is also a strong indication that SARA occurred in cows fed these diets. These fiber-based criteria do not account for differences in the ruminal fermentability of concentrates that can have a major effect on ruminal pH (Krause et al., 2002; Rustomo et al., 2006b; Plaizier et al., 2008). The utilization of feedstuffs with a high rate of fermentation in $\mathrm{M}$ and $\mathrm{R}$ diets may have contributed to enhance the effects of low FNDF and peNDF content on ruminal fermentation. Limiting the duration of access to the manger, although it is not necessary a common practice in dairy farms, was chosen to avoid a trend toward taking small meals (Le Liboux and Peyraud, 1999; Lechartier and Peyraud, 2010). It also increases the mean eating rate (Campling and Morgan, 1981) and meal size. This was, in principle, more favorable for observing any response to variations in diet characteristics.

\section{Effect of CRDM and Type of Carbohydrate on DMI}

Dry matter intake decreased sharply with increasing CRDM, confirming previous data reported by Lechartier and Peyraud (2010). Overton et al. (1995) also reported a significant decrease in DMI when increasing CRDM by replacing ground shelled corn with steam-rolled barley without modifying the forage-to-concentrate ratio. The present study showed that this effect was linear, the slope being $-2.4 \mathrm{~kg} / \mathrm{d}$ per $10 \%$ increase in CRDM. It also showed that the effect occurred in HS and LS diets, and was, therefore, a specific effect of

Table 6. Effects of dietary content of rapidly degradable DM from concentrate (CRDM) and starch (St) on fractional outflow rate of liquid (FORL), liquid volume, and liquid outflow from the rumen

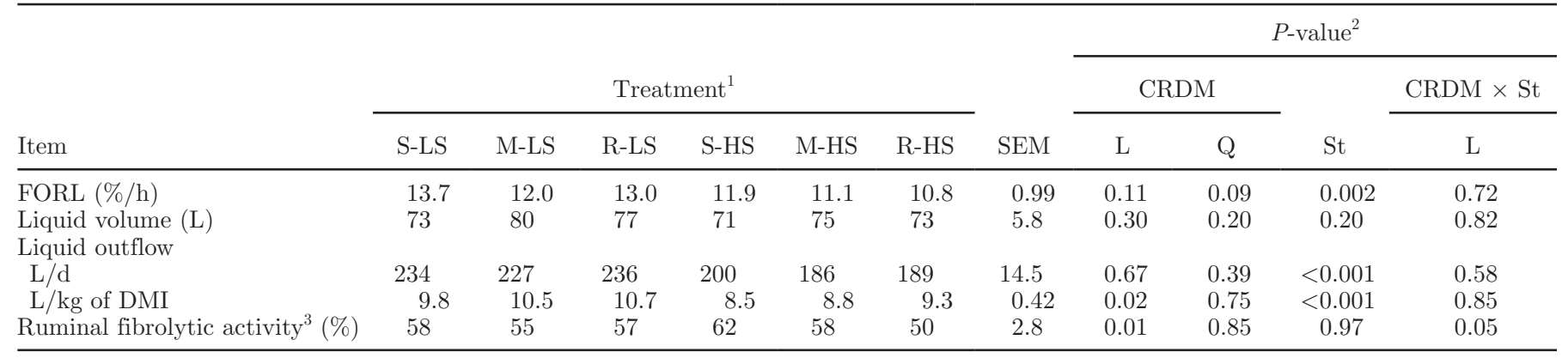

${ }^{1} \mathrm{~S}, \mathrm{M}$, and $\mathrm{R}=$ slowly, moderately, and rapidly degradable concentrate, respectively; LS and HS = low and high dietary starch content, respectively.

${ }^{2} \mathrm{~L}=$ linear; $\mathrm{Q}=$ quadratic.

${ }^{3}$ Disappearance rate of soybean hulls DM incubated in nylon bags for $24 \mathrm{~h}$. 
Table 7. Effects of dietary contents of rapidly degradable DM from concentrate (CRDM) and starch (St) on milk yield, milk composition, and milk fatty acids yields

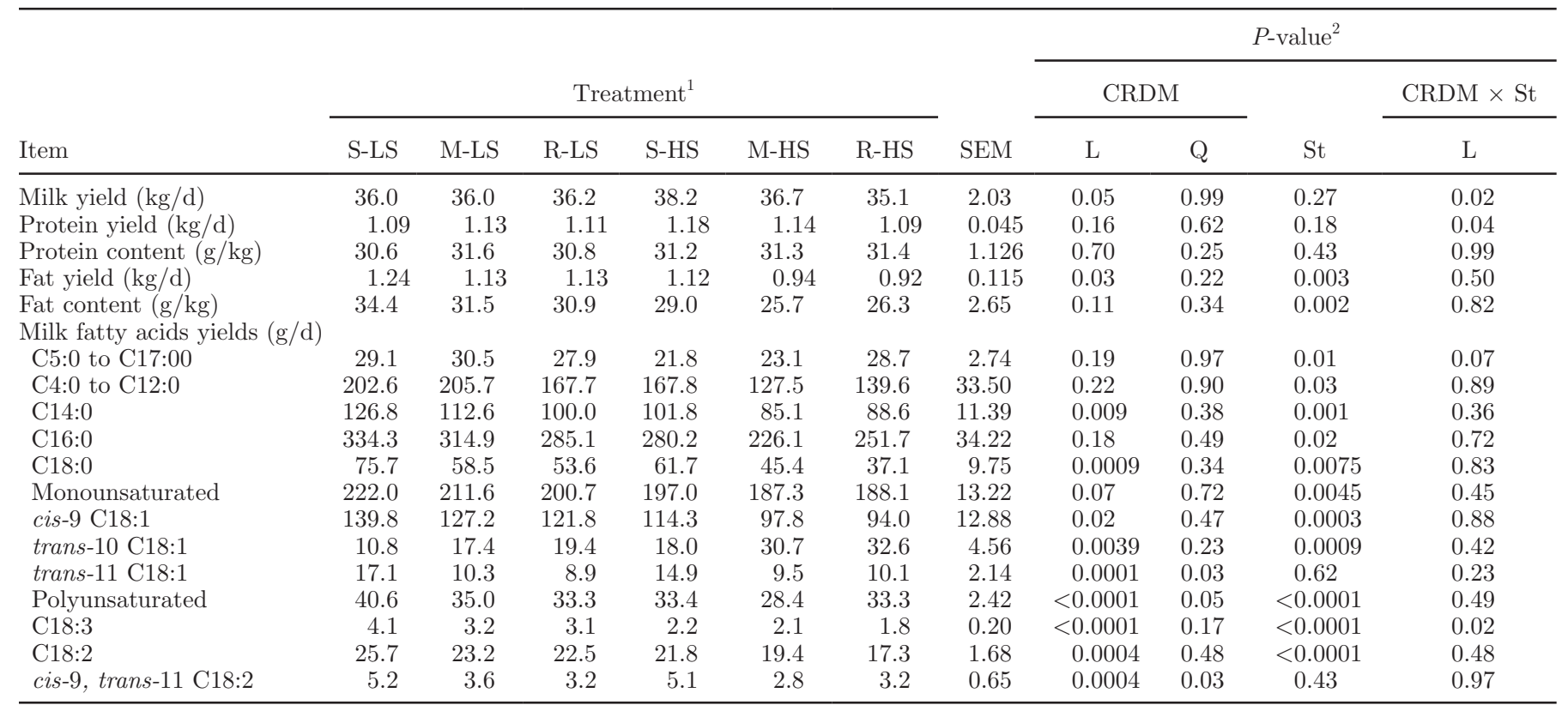

${ }^{1} \mathrm{~S}, \mathrm{M}$, and $\mathrm{R}=$ slowly, moderately, and rapidly degradable concentrate, respectively; LS and HS = low and high dietary starch content, respectively.

${ }^{2} \mathrm{~L}=$ linear; $\mathrm{Q}=$ quadratic.

CRDM. High CRDM levels are likely to involve marked feedback effects on homeostatic regulation of intake. The cows might have adjusted intake in response to the increased molar proportion of propionate with increasing CRDM. Propionate could have decreased DMI by increasing insulin secretion, as proposed by Grovum (1995). Alternatively, the greater increase in VFA range under high-CRDM diets would have led to a decrease in DMI to avoid excessive rumen acid load or osmostic pressure (Bergen, 1972). The cows may also have adjusted their intake in response to lower ruminal $\mathrm{pH}$. Krause et al. (2002) have previously reported the relationship between the extent of ruminal $\mathrm{pH}$ depression and the decrease in DMI.

Feeding HS diets decreased DMI $(-0.9 \mathrm{~kg} / \mathrm{d})$ across levels of CRDM. Some authors reported no effect on DMI when replacing beet pulp by high-moisture corn (Voelker and Allen, 2003a) or soybean hulls by dry corn (Cunningham et al., 1993; Ipharraguerre et al., 2002). However, in these studies, the variation in the dietary starch content is partly confounded with the variation in CRDM. This decrease in DMI could be partly explained by the increased proportion of propionate under HS diets, as discussed above. Alternatively, higher dietary protein content in LS diets compared with HS diets might have contributed to a higher level of intake especially when feeding diets rich in highly degradable carbohydrates. Vérité and Delaby (2000) have previously reported an increase in DMI when increasing protein content in diets rich in concentrates.

It is generally agreed that SARA occurs in repeated periods of depressed $\mathrm{pH}$ below 5.6 to 5.8 (Beauchemin et al., 2003; Rustomo et al., 2006a; Yang and Beauchemin, 2009). In the present experiment, the nadir of $\mathrm{pH}$ barely reached these threshold values, which is possibly related to the rate of decrease of DMI as dietary starch and CRDM contents increased.

\section{Effects of CRDM and Type of Carbohydrate on the Dynamics of Ruminal Fermentation}

Rumen $\mathrm{pH}$ and its daily fluctuations are crucial elements for the regulation of microbial activity. This raised the problem of finding one of several variables that could accurately describe the various aspects of ruminal $\mathrm{pH}$ dynamics. The duration during which $\mathrm{pH}$ remains below a critical value is often considered as more important than the average $\mathrm{pH}$ because cellulolytic activity rapidly decreases when $\mathrm{pH}$ falls below about 6.0 to 5.8 (Mould et al., 1984). In our study the time during which $\mathrm{pH}$ was below 6.0 and the area under the $\mathrm{pH} 6.0$ curve were highly correlated to the mean $\mathrm{pH}$, whereas $\mathrm{pH}$ range was not. From a quantitative review of the literature, Dragomir et al. (2008) have also reported a far lower correlation between mean $\mathrm{pH}$ and $\mathrm{pH}$ range than between mean $\mathrm{pH}$ and time of $\mathrm{pH}$ 
below 6.0. Therefore, mostly mean $\mathrm{pH}$ and $\mathrm{pH}$ range were further considered.

Increasing CRDM increased $\mathrm{pH}$ range and VFA range. It also boosted the initial rate of VFA increase and the initial rate of $\mathrm{pH}$ decrease. In agreement with Lechartier and Peyraud (2010), these findings suggest that increasing CRDM increases the rate and amount of acid production during and just after the meal, which, in turn, leads to a greater $\mathrm{pH}$ decrease. Increasing CRDM did not affect total eating time, suggesting that saliva secretion did not play a major regulatory role in the dynamics of $\mathrm{pH}$ during the early stages of fermentation. Our results also demonstrated that nonstarch feedstuffs - especially those with a high pectin content (i.e., M-LS and R-LS diets) — can be highly fermentable in vivo. Using an in vitro technique, de Smet et al. (1995) and Rustomo et al. (2006b) determined the acidogenicity of several feedstuffs and showed that pectin-rich feedstuffs such as beet pulp are even more acidogenic than rapidly fermented starch-rich feedstuffs. Malestein et al. (1984) have previously reported that citrus pulp leads to a lower in vivo $\mathrm{pH}$ than does corn grain.

The post-feeding range of VFA was high $(+44 \mathrm{mM})$ and similar under LS and HS diets. Therefore, it appears that the ability of feedstuffs to increase VFA production in a relatively short period of time after the beginning of the meal can be predicted from the in sacco disappearance of DM after $4 \mathrm{~h}$ of incubation, irrespective of type of carbohydrate. Moreover, lactate concentration peaked higher under LS diets. These findings suggest that nonstarch feedstuffs can be highly degradable and degraded just as rapidly as starch-rich feedstuffs.

Feeding LS diets decreased the $\mathrm{pH}$ range, whereas VFA range did not differ between the 2 types of carbohydrate for a similar CRDM, thus suggesting a higher buffering capacity of LS diets. This might be related to the higher CP content in LS diets compared with HS diets, as protein degradation produces bicarbonates. Moreover, the increase in CP content between S-LS and R-LS diets might have contributed to increasing the buffering capacity of ruminal content when increasing CRDM in LS diets. Alternatively, McBurney et al. (1983) showed that the cation-exchange capacity of nonstarch feedstuffs is higher than that of starch-rich feedstuffs, this property of nonstarch feedstuffs being explained through their ability to attract and bind hydrogen ions. Therefore, highly digestible nonstarch feedstuffs might contribute to a small extent to the buffering capacity of the rumen compared with highly digestible starch-rich feedstuffs during the early stages of digestion.

The effect of CRDM and type of carbohydrate on mean $\mathrm{pH}$ and mean VFA concentration are different than short-term effects. Increasing CRDM linearly decreased the mean ruminal $\mathrm{pH}$ under LS diets but linearly increased it under HS diets, thus resulting in a lower mean $\mathrm{pH}$ and a higher mean VFA concentration with M-LS and R-LS diets compared with M-HS and R-HS diets, whereas type of carbohydrate had no effect when feeding slowly degradable feedstuffs. Initial $\mathrm{pH}$ (i.e., $\mathrm{pH}$ before the beginning of the meal) followed similar trends to that of mean pH. Kung et al. (1992) also reported a simultaneously higher $\mathrm{pH}$ range and higher initial $\mathrm{pH}$ when substituting dry corn grain with barley in steer diets. The literature does not highlight a systematic pattern for the effects of type of carbohydrate on mean ruminal $\mathrm{pH}$. Replacing nonstarch feedstuffs by starch-rich feedstuffs often leads to a decrease in ruminal pH (Huhtanen, 1988; Batajoo and Shaver, 1994; Silveira et al., 2007). However, in these studies, the increasing amounts of starch were associated with increasing CRDM, as calculated in the present study. It should be underlined that when CRDM was marginally affected by a change in carbohydrate type, replacing nonstarch feedstuffs by starch-rich feedstuffs decreased VFA concentrations (Elliott et al., 1995; Broderick et al., 2002).

The effects of CRDM and type of carbohydrate on mean fermentation parameters are probably more related to between-treatments changes in VFA production and removal than changes in ruminal buffering capacity, as suggested by the relationship between VFA concentration and mean ruminal $\mathrm{pH}$, which did not differ between LS and HS diets. The average time spent chewing did not vary between treatments, suggesting that salivary flow was not affected (Allen, 1997). With HS diets, increasing CRDM linearly decreased the ruminal fibrolytic activity estimated from the disappearance of soybean hulls DM after $24 \mathrm{~h}$ of in sacco incubation, which, in turn, might have slowed the digestion of slowly degradable fractions of the diet. Consequently, acid production also might have been slowed, resulting in a higher initial $\mathrm{pH}$ before the following meal. The decrease in DMI observed when M-HS and R-HS diets were fed might also have contributed to the increase in initial $\mathrm{pH}$ and mean $\mathrm{pH}$ (Mulligan et al., 2002). Conversely, with LS diets, increasing CRDM did not affect ruminal fibrolytic activity, which would have prevented initial $\mathrm{pH}$ from recovering high values. The faster rate of $\mathrm{pH}$ increase after the peak of fermentation (estimated by the final rate of $\mathrm{pH}$ increase) under HS diets also confirms a more transient ruminal fermentation. This also suggests that increasing the diet content of highly degradable starch impaired fibrolytic activity independently of its effect on ruminal $\mathrm{pH}$.

The lactate concentration peak was lower under HS than LS diets, but lactate concentration remained at 
higher levels from 1100 to $1700 \mathrm{~h}$. These results could be explained by an engulfment of starch granules by protozoa (Jouany and Ushida, 1999), which could have moderately slowed the digestion of starch during the first few hours. The gradual release of starch would have certainly maintained a higher production of lactate.

During the first few hours following the meal, pectinrich feedstuffs produced at least as much VFA and lactate as starch-rich feedstuffs, but with a slightly lower decrease in $\mathrm{pH}$ due to their ability to attract and bind hydrogen ions. However, contrary to starch-rich feedstuffs, pectin-rich feedstuffs did not decrease fibrolytic activity, which would lead to a more intense production of acid, even long after meals. As this acid production was less buffered, because the pectin was almost entirely fermented at these times, the mean ruminal $\mathrm{pH}$ decreased significantly. Pectin-rich feedstuffs appear to be more acidogenic than are starch-rich feedstuffs. It should be noted that M-LS and R-LS diets led to the highest mean ruminal VFA concentrations. Lechartier and Peyraud (2010) concluded that fibrolytic activity would be more sensitive to the total range of $\mathrm{pH}$ variations rather than mean $\mathrm{pH}$. The findings reported here suggest that the negative effect of increasing $\mathrm{pH}$ range on fibrolytic bacteria activity is counteracted when giving nonstarch feedstuffs. This could be related to a higher amount of substrate available for bacteria liable to degrade fiber.

\section{Effects of CRDM and Type of Carbohydrate on End-Products of Ruminal Fermentation}

Increasing CRDM decreased the relative proportion of acetate and increased the relative proportion of propionate, consistent with our previous results (Lechartier and Peyraud, 2010). Many studies in which slowly degradable starch was replaced with rapidly degradable starch (Overton et al., 1995; Krause et al., 2002) have shown a decrease in acetate-to-propionate ratio. However, as far as we know, the response of ruminal VFA profile to increased amounts of degradable carbohydrates has not yet been described for nonstarch feedstuffs. Furthermore, the present study demonstrates that the effect is linear with increasing CRDM, and is similar across nonstarch and starch-rich feedstuffs. Thus, CRDM affects the relative proportion of VFA, independently of type of carbohydrate.

Feeding HS diets decreased the acetate-to-propionate ratio, independently of CRDM. This result is consistent with many other studies in which starch-rich feedstuffs were replaced by nonstarch feedstuffs (Ipharraguerre et al., 2002; Voelker and Allen, 2003b), including studies where the substitution of starch-rich feedstuffs with nonstarch feedstuffs only marginally affected CRDM (Elliott et al., 1995; Broderick et al., 2002).

An in vitro study by Calsamiglia et al. (2008) showed that acetate production decreases at low $\mathrm{pH}$ due to a decrease in the activity of fibrolytic bacteria (Hoover, 1986), which are acetate-producers. Conversely, propionate production increases due to the ability of starch-degrading bacteria, which preferentially produce propionate, to adapt to low-pH environments (Russell, 1998). Here, increasing CRDM decreased the acetateto-propionate ratio for both LS and HS diets, whereas its effects on mean $\mathrm{pH}$ differed according to type of carbohydrate. The $\mathrm{pH}$ range appeared to produce a stronger effect on VFA profile than did mean $\mathrm{pH}$ or time during which $\mathrm{pH}$ was below 5.8 or 6.0 . These findings suggest that VFA profile is dependent on the amount of energy available to rumen microbes, as previously stated by Sauvant and Van Milgen (1995), and that the decrease of $\mathrm{pH}$ during the early stages of digestion has a major effect:

$$
\begin{aligned}
& \mathrm{C} 2 / \mathrm{C} 3=3.60-1.32 \times \mathrm{pH} \text { range } \\
& \left(\mathrm{n}=36 ; \mathrm{RSD}=0.45 ; \mathrm{r}^{2}=0.45\right) .
\end{aligned}
$$

The linear increase in the yield of trans-10 C18:1 in milk with increasing CRDM, along with the linear decrease in the yield of trans-11 C18:1, suggests a shift in the biohydrogenation pathways of $\mathrm{C} 18: 2$, which became oriented to trans-10 C18:1 instead of trans-11 C18:1 (Bauman and Griinari, 2003). Kalscheur et al. (1997) showed that trans-10 C18:1 was produced when mean ruminal $\mathrm{pH}$ decreased. This was not the case in our study, where the yield of trans-10 C18:1 increased by $70 \%$ under HS diets, although the mean $\mathrm{pH}$ was higher under HS diets than under LS diets, thus suggesting a specific effect of type of substrate fermented on the regulation of biohydrogenation pathways. Alternatively, the decrease in $\mathrm{pH}$ range appears much more predictive of the shift between the 2 biohydrogenation pathways than does mean ruminal $\mathrm{pH}$, as reported above for the regulation of VFA profiles. Indeed the production of trans-10 $\mathrm{C} 18: 1$ and the ratio between trans-10 $\mathrm{C} 18: 1$ and trans-11 $\mathrm{C} 18: 1$ are closely correlated to the ruminal acetate-to-propionate ratio:

$$
\begin{gathered}
\text { trans-10 C18:1 }(\mathrm{g} / \mathrm{d})=60.4-16.7 \times \mathrm{A}: \mathrm{P} \\
\left(\mathrm{n}=36 ; \mathrm{RSD}=8.44 ; \mathrm{r}^{2}=0.59\right) . \\
\text { CONCLUSIONS }
\end{gathered}
$$

\section{CONCLUSIONS}

This experiment was designed to dissociate the effects of the type of carbohydrates (starch-rich vs. non- 
starch feedstuffs) and the dietary content of rapidly degradable carbohydrates on ruminal fermentation. Both factors had major and independent effects. The effects of the dietary contents of starch and rapidly degradable carbohydrates on mean ruminal $\mathrm{pH}$ were not additive, contrary to their effects on $\mathrm{pH}$ range. The increase in the $\mathrm{pH}$ range when increasing dietary starch and rapidly degradable carbohydrate contents was due to a lower cation-exchange capacity of the feedstuffs and a higher rate of VFA production during the first few hours post-feeding, respectively. The interaction between the dietary starch content and rapidly degradable carbohydrates on mean ruminal $\mathrm{pH}$ was due to a long-term regulation of acid production. When feeding rapidly degradable carbohydrates, increasing dietary starch content decreased fibrolytic activity, leading to lower VFA production under starch-rich diets. The VFA profile is affected by dietary content in rapidly degradable carbohydrates, which determines fermentation dynamics, and by the proportion of starch in the diet. Finally, these 2 dietary factors have to be considered simultaneously to predict the VFA profile. The results of this experiment clearly show that, besides the supply of physically effective fiber, both the fermentative characteristics of the concentrate and its starch content should be taken into account when formulating diets to prevent SARA.

\section{ACKNOWLEDGMENTS}

This study was given financial supported from Conseils et Compétences en Productions Animales (CCPA; Janzé, France) and Techna (Couëron, France). We particularly thank Thierry Aubert (CCPA) and Emmanuel David (Techna) for enriching discussions on this trial. We are grateful to Philippe Lamberton and the farm staff (INRA, Le Rheu, France) for cow welfare, feeding, and sampling. The authors also thank Thibaud Le Mouel, Sandrine Jaguelin, and Nicole Huchet (all from INRA, Saint-Gilles, France) for technical assistance, and A. T. T. (Clermont-Ferrand, France) for correction of the English version of the manuscript.

\section{REFERENCES}

Allen, M. S. 1997. Relationship between fermentation acid production in the rumen and the requirement for physically effective fiber. J. Dairy Sci. 80:1447-1462.

Apper-Bossard, E., J. L. Peyraud, P. Faverdin, and F. Meschy. 2006. Changing dietary cation-anion difference for dairy cows fed with two contrasting levels of concentrate in diets. J. Dairy Sci. 89:749-760.

Association Française de Normalisation. 1985. Aliments des animaux. Méthodes d'analyses françaises et communautaires. Dosage de l'amidon. Pages 123-125 in Méthode polarimétrique. 2nd ed. Association Française de Normalisation, Paris, France.
Batajoo, K. K., and R. D. Shaver. 1994. Impact of nonfiber carbohydrate on intake, digestion, and milk production by dairy cows. J. Dairy Sci. 77:1580-1588.

Bauman, D. E., and J. M. Griinari. 2003. Nutritional regulation of milk fat synthesis. Annu. Rev. Nutr. 23:203-227.

Beauchemin, K. A., W. Z. Yang, and L. M. Rode. 2003. Effects of particle size of alfalfa based dairy cow diets on chewing activity, ruminal fermentation, and milk production. J. Dairy Sci. 86:630643.

Bergen, W. G. 1972. Rumen osmolality as a factor in feed intake control of sheep. J. Anim. Sci. 34:1054-1060.

Broderick, G. A., D. R. Mertens, and R. Simons. 2002. Efficacy of carbohydrate sources for milk production by cows fed diets based on alfalfa silage. J. Dairy Sci. 85:1767-1776.

Calsamiglia, S., P. W. Cardozo, A. Ferret, and A. Bach. 2008. Changes in rumen microbial fermentation are due to a combined effect of type of diet and pH. J. Anim. Sci. 86:702-711.

Campling, R. C., and C. A. Morgan. 1981. Eating behaviour of housed dairy cows - A review. J. Dairy Sci. Abstr. 43:57-63.

Cunningham, K. D., M. J. Cecava, and T. R. Johnson. 1993. Nutrient digestion, nitrogen, and amino-acid flows in lactating cows fed soybean hulls in place of forage or concentrate. J. Dairy Sci. 76:3523-3535.

de Smet, A. M., J. L. de Boever, D. L. de Brabander, J. M. Vanacker, and Ch. V. Boucqué. 1995. Investigation of dry matter degradation and acidotic effect of some feedstuffs by means of in sacco and in vitro incubations. Anim. Feed Sci. Technol. 51:297-315.

Dragomir, C., D. Sauvant, J.-L. Peyraud, S. Giger-Reverdin, and B. Michalet-Doreau. 2008. Meta-analysis of 0 to $8 \mathrm{~h}$ post-prandial evolution of ruminal pH. Animal 2:1437-1448.

Elliott, J. P., J. K. Drackley, G. C. Fahey Jr., and R. D. Shanks. 1995. Utilization of supplemental fat by dairy cows fed diets varying in content of nonstructural carbohydrates. J. Dairy Sci. 78:15121525 .

Gill, J. L. 1978. Completely randomized designs of analysis of variance. Pages 135-258 in Design and Analysis of Experiments in the Animal and Medical Sciences. Vol. 1. Iowa State Univ. Press, Ames.

Grovum, W. L. 1995. Mechanisms explaining the effects of short chain fatty acids on feed intake in ruminants - Osmotic pressure, insulin and glucagon. Pages 173-197 in Ruminant Physiology: Digestion, Metabolism, Growth and Reproduction. W. V. Englehardt, S. Leonhard-Marek, G. Breves, and D. Geisecke, ed. Ferdinand Enke Verlag, Stuttgart, Germany.

Hoover, W. H. 1986. Chemical factors involved in ruminal fiber digestion. J. Dairy Sci. 69:2755-2766.

Huhtanen, P. 1988. The effects of barley, unmolassed sugar-beet pulp and molasses supplements on organic matter, nitrogen and fibre digestion in the rumen of cattle given a silage diet. Anim. Feed Sci. Technol. 20:259-278.

Hurtaud, C., H. Rulquin, and R. Vérité. 1993. Effect of infused volatile fatty acids and caseinate on milk composition and coagulation in dairy cows. J. Dairy Sci. 76:3011-3020.

INRA. 1989. Ruminant Nutrition: Recommended Allowances and Feed Tables. R. Jarrige, ed. John Libbey, Eurotext, London, UK.

INRA-AFZ. 2004. Tables of Composition and Nutritional Value of Feed Materials. 2nd revised and corrected edition. D. Sauvant, J.M. Perez, and G. Tran, ed. INRA, Paris, France.

Ipharraguerre, I. R., Z. Shabi, J. H. Clark, and D. E. Freeman. 2002. Ruminal fermentation and nutrient digestion by dairy cows fed varying amounts of soyhulls as a replacement for corn grain. J. Dairy Sci. 85:2890-2904.

Jouany, J. P., and K. Ushida. 1999. The role of protozoa in feed digestion-Review. Asian-australas. J. Anim. Sci. 12:113-128.

Kalscheur, K. F., B. B. Teter, L. S. Piperova, and R. A. Erdman. 1997. Effect of dietary forage concentration and buffer addition on duodenal flow of trans-C18:1 fatty acids and milk fat production in dairy cows. J. Dairy Sci. 80:2104-2114.

Kononoff, P. J., A. J. Heinrichs, and D. R. Buckmaster. 2003. Modification of the Penn State forage and total mixed ration particle 
separator and the effects of moisture content on its measurements. J. Dairy Sci. 86:1858-1863.

Krause, K. M., D. K. Combs, and K. A. Beauchemin. 2002. Effects of forage size and grain fermentability in midlactation cows. II. Ruminal pH and chewing activity. J. Dairy Sci. 85:1947-1957.

Kung, L. Jr., R. S. Tung, and B. R. Carmean. 1992. Rumen fermentation and nutrient digestion in cattle fed diets varying in forage and energy source. Anim. Feed Sci. Technol. 39:1-12.

Le Liboux, S., and J. L. Peyraud. 1999. Effect of forage particle size and feeding frequency on fermentation patterns and sites and extent of digestion in dairy cows fed mixed diets. Anim. Feed Sci. Technol. 76:297-319.

Lechartier, C., and J. L. Peyraud. 2010. The effects of forage proportion and rapidly degradable dry matter from concentrate on ruminal digestion in dairy cows fed corn silage-based diets with fixed neutral detergent fiber and starch contents. J. Dairy Sci. 93:666-681.

Malestein, A., A. Th. van't Klooster, R. A. Prins, and G. H. M. Counotte. 1984. Concentrate feeding and ruminal fermentation. 3. Influence of concentrate ingredients on $\mathrm{pH}$, on DL-lactic acid concentration in rumen fluid of dairy cows, and on dry matter intake. Neth. J. Agric. Sci. 32:9-21.

McBurney, P. J., I. Michael, L. van Soest, and E. Chase. 1983. Cation exchange capacity and buffering capacity of neutral-detergent fibres. J. Sci. Food Agric. 34:910-916.

Mertens, D. R. 1997. Creating a system for meeting the fiber requirements of dairy cows. J. Dairy Sci. 80:1463-1481.

Michalet-Doreau, B., R. Vérité, and P. Chapoutot. 1987. Méthodologie de mesure de la dégradabilité in sacco de l'azote des aliments dans le rumen. Bull. Tech. CRZV Theix, INRA. 69:5-7.

Mould, F. L., E. R. Ørskov, and S. O. Mann. 1984. Associative effect of mixed feeds. I. Effects of type and level of supplementation and the influence of the rumen fluid $\mathrm{pH}$ on cellulolysis in vivo and dry matter digestion of various roughages. Anim. Feed Sci. Technol. $10: 15-30$

Mulligan, F. J., P. J. Caffrey, M. Rath, J. J. Callan, P. O. Brophy, and F. P. O'Mara. 2002. An investigation of feeding level effects on digestibility in cattle for diets based on grass silage and high fibre concentrates at two forage:concentrate ratios. Livest. Prod. Sci. $77: 311-323$.

NRC. 2001. Nutrient Requirements of Dairy Cattle. 7th rev. ed. National Academy of Sciences, Washington, DC.

Overton, T. R., M. R. Cameron, J. P. Elliott, J. H. Clark, and D. R. Nelson. 1995. Ruminal fermentation and passage of nutrients to the duodenum of lactating cows fed mixture of corn and barley. J. Dairy Sci. 78:1981-1998.

Plaizier, J. C., D. O. Krause, G. N. Gozho, and B. W. McBride. 2008. Subacute ruminal acidosis in dairy cows: The physiological causes, incidence and consequences. Vet. J. 176:21-31.

Robinson, P. H., S. Tamminga, and A. M. van Vuuren. 1986. Influence of declining level of feed intake and varying the proportion of starch in the concentrate on rumen fermentation in dairy cows. Livest. Prod. Sci. 15:173-189.

Russell, J. B. 1998. The importance of $\mathrm{pH}$ in the regulation of ruminal acetate-to-propionate ratio and methane production in vitro. $\mathrm{J}$. Dairy Sci. 81:3222-3230.

Rustomo, B., O. AlZahal, N. E. Odongo, T. F. Duffield, and B. W. McBride. 2006a. Effects of rumen acid load from feed and forage particle size on ruminal $\mathrm{pH}$ and dry matter intake in the lactating dairy cows. J. Dairy Sci. 89:4758-4768.

Rustomo, B., J. P. Cant, M. Z. Fan, T. F. Duffield, N. E. Odongo, and B. W. McBride. 2006b. Acidogenic value of feeds. I. The relationship between the acidogenic value of feeds and in vitro ruminal ph changes. Can. J. Anim. Sci. 86:109-117.

SAS Institute. 1999. SAS User's Guide: Statistics. Version 8.01. SAS Inc., Cary, NC.

Sauvant, D., and J. van Milgen. 1995. Dynamic aspects of carbohydrate and protein breakdown and the associated microbial matter synthesis. Pages 71-91 in Ruminant physiology: Digestion, metabolism, growth and reproduction. Proc. 8th International Symposium on Ruminant Physiology. W. V. Engelhardt, S. LeonardMarek, G. Breves, and D. Giesecke, ed. Ferdinand Enke Verlag, Stuttgart, Germany.

Silveira, C., M. Oba, W. Z. Yang, and K. A. Beauchemin. 2007. Selection of barley grain affects ruminal fermentation, starch digestibility, and productivity of lactating dairy cows. J. Dairy Sci. 90:2860-2869.

Udén, P., P. E. Colucci, and P. J. Van Soest. 1980. Investigation of chromium, cerium and cobalt as markers in digesta. Rate of passage studies. J. Sci. Food Agric. 31:625-632.

Vérité, R., and L. Delaby. 2000. Relation between nutrition, performances and nitrogen excretion in dairy cows. Ann. Zootech. 49:217-230.

Vérité, R., B. Michalet-Doreau, F. Vedeau, and P. Chapoutot. 1990. Dégradabilité en sachets des matières azotées des aliments concentrés: Standardisation de la méthode et variabilité intra et inter laboratoires. Reprod. Nutr. Dev. 30(Suppl. 2):161s-162s.

Voelker, J. A., and M. S. Allen. 2003a. Pelleted beet pulp substituted for high-moisture corn: 1. Effects on feed intake, chewing behavior, and milk production of lactating dairy cows. J. Dairy Sci. 86:3542-3552.

Voelker, J. A., and M. S. Allen. 2003b. Pelleted beet pulp substituted for high-moisture corn: 3. Effects on ruminal fermentation, $\mathrm{pH}$, and microbial protein efficiency in lactating dairy cows. J. Dairy Sci. 86:3562-3570

Yang, W. Z., and K. A. Beauchemin. 2009. Increasing physically effective fiber content of dairy cow diets through forage proportion versus forage chop length: Chewing and ruminal pH. J. Dairy Sci. 92:1603-1615. 